\title{
The Psycho-Social Aspect of Indecent Dressing: Influence of Gender, Dress Pattern and Physical Attractiveness on Sexual Harassment
}

\author{
Alhaji Ahmadu Ibrahim ${ }^{* 1}$ and Ali Haruna ${ }^{* 2}$ \\ ${ }^{1,2}$ Department of Sociology, Yobe State University Damaturu. Nigeria.
}

\begin{abstract}
The study investigated the Psycho-social Aspect of Indecent Dressing: Influence of Gender, Dress Pattern and Physical Attractiveness on Sexual Harassment among University Undergraduates Students. 100 Undergraduate students of Yobe State University participated in the study.Dress pattern questionnaire (DPQ) was used to measure dressing pattern (Decent $x$ Indecent), photographs were used to assess physical attractiveness and the Sexual Harassment Questionnaire (SHQ) was used as the dependent measure. The results were statistically significant for Gender $F(1,100)=5.885, P<0.05$ and Dress Pattern, $F(1,100)=719, P<$ 0.05. The implication of this finding is that those students who dress indecently and who are females whether attractive or unattractive are highly prone to Sexual Harassment.
\end{abstract}

\section{Introduction}

Unsolicited and unwelcomed sexual behavour has been with us right from the time man appeared on earth. It is called harassment because the consent of the partner is often not sought or obtained. With the advent of modernity, sexual harassment has assumed different forms or methods. There has, recently been an increasing attention given to sexual harassment most especially among undergraduate students all over the world. Several underlying factors have been held responsible for this. There is consensus among researchers that sexual orientation and behaviour constitute the major factors in the etiology of sexual harassment.

Equally Employment Opportunity Commission (2002) defines sexual harassment as unwelcome sexual advances, request for sexual favours, and other verbal or physical conduct of a sexual nature constitute sexual harassment when submission to or rejection of this conduct explicitly or implicitly affects an individual's employment, unreasonably interferes with an individual's work performance or creates an intimidating, hostile or offensive work environment. Generally put, sexual harassment could be done by a supervisor, co-workers, classmates, stranger, a friend, a client, a family member etc. several theories have been proposed to explain the concept.

The sociological perspective holds that men are biologically programmed to be sexually aggressive and that sexual behaviour in work place is one aspect of that biological inheritance. This perspective therefore considers sexual aggression as biologically normal. The patriarchy perspective holds that the cultural structure of patriarchy (Rule by the Fathers) is the root cause of sexual harassment. Within this social structure, men have social, political, and economic power over women, who are defined by the system as sexual in nature. Discursive perspective holds that communication creates and shapes social reality. Those communication activities reproduces and sustain oppressive conditions such as sexual harassment. This perspective implies that to remedy sexual harassment, the way discursive practices sustain oppression must be analysed and work toward changing those practices by changing the laws and norms of behaviour. Recently however, several factors are held as culprits of sexual harassment; these includes gender, dress pattern, physical attractiveness etc.

Gender has been implicated in sexual harassment. For example, Studd \$ Gattiker (1991) explained from a more biological perspective that sexual harassment is a natural outcomes of men's stronger sex drive and their roles as the sexual aggressors. Some researchers also perceive sexual harassment as a product of gender socialization process that facilitates marginalization of women both at work and in the society generally. For instance, Whatiel and Wasieleski (2001) found marginally significant gender differences in sexual harassment where female participants reported more gender harassment than male participants.

Apart from gender being a factor in sexual harassment, Foster (1996) found indecent dressing to be another major factor. He found that girls who frequently wear indecent dresses perceive themselves as special, thus their predisposition to be sexually harassed. Similarly, Buunk, Siero and Vanden Eijnden (2000) found indecently dressed persons to be involved in the behaviour as a reaction to more beautiful persons in order to attract the attention of the opposite sex. Bojos and Marquet (2000) investigated common types of indecent dresses on campuses i.e the elitist, the amorous, the unprincipled and the compensatory indecent dressing. The elitist seductive dressers are usually from privileged and economically empowered background. They often 
flaunt their salient features like the breast, and pubic in attempt to promote themselves which make them very prone to sexual harassment. Bojos, Marquet and McPhal (2000) found that most of such students' parents are in the upper classes. That they always try to maintain an above average academic performance as part of the seduction.

Amorous indecent dressers are sexually seductive, but often avoid real intimacy. They simply play games by deceptively seducing their preys for economic purposes. The unprincipled indecent dressers on the other hand are unscrupulous, deceptive, arrogant and exploitative. In contrast to the others. The compensatory indecent dressers do so to cover up for their feelings of inferiority. They only try to create illusions of being superior and exceptional on campus by dressing indecently. One major finding about indecently dressed females is that, they have maladaptive ideas about themselves particularly the blief that they are pleasurable and deserve to be treated as such. Carvajal, Garner and Evans (2005) in their study found support for this hypotheses. They found such beliefs by the females to hamper their abilities to perceive their experiences realistically and that they often encounter problems when their indecent dressing clash with an experience of relationship failures.

The twenty-first century heralded the emergence of the obnoxious purported sexual harassment of female students by some lectures in tertiary institution in Nigeria, Yobe State University inclusive. The complaint was that some male lectures demanded sex from female students in exchange for better grades. The media reported many students complaining of being routinely propositioned by lecturers during working hours. Baine (2008) explained that sexual harassment is basically about power, that is, it depends on who has more power. By implication, a female student can equally sexually harass a lecturer in the way she dresses. Indecent dressing that expose the breast, buttocks and thighs constitute some forms of sexual harassment.

Physically attractiveness is another factor in sexual harassment. Evolutionary Psychology posits that physical attraction in human is related directly to sexual selection and reproductive success. This is why humans have viewed certain features as attractive because these features are evident in healthy individuals (Fink and Penton Voak, 2002). Researchers also show that males are more influenced by looks. Resaerchers such as Feingold (1990, \$ 1991) and Sprecher (1994) found males to value the physical attractiveness of the opposite sex. Even though there are advantages of being beautiful and attractive, Hatfield and Sprecher (1986) reported that there is also an ugly truth about beauty. Those exceptionally attractive individuals are prone to unwelcome sexual advances or resentment from persons of the same sex.

According to Dion, Benscheiid and Walster (1992) physically attractive people are perceived in a positive fashion than the physically unattractive defendant. It is common knowledge that attractive men do not need to sexually harass women. They can always get all the sex they need without resorting to harassment. In most instances, sexual advances by attractive men are unlikely to be taken as harassment. Similarly, men would most unlikely be motivated to harass unattractive women.

From research results as presented above the factors responsible for sexual harassment are many. Particular this study is interested in the extent to which gender, dress patent and physical attractiveness influenced sexual harassment.

The following questions have been paged to be answered by this study.

* Does students who dress indecently likely experience higher level of sexual harassment than those that dress decently?

* Is physically attractive females likely to experience higher level of sexual harassment than physically attractive males?

*Will sexual harassment likely be the function of the gender and dress pattern among participants?

* Would there be interaction effects on the three factors on sexual harassment.

\section{Participants}

\section{Methods}

In recent times higher institutions of learning particularly those in Nigeria have been identified as communities where the incidence of sexual harassment is very high. This outcry informed the choice of the university as the site of this study. The participants for the study were undergraduate students of the Yobe State University Damaturu. They were drawn from 13 Departments made up of 100 students (50 males and 50 females). 23 of them were in their first year, 27 in their second year, 27 in their third year, and 23 in their fourth year. 81 of them were single students and 19 were married. Their age range was 18-42 years.

\section{Instrument}

The three instruments used in this study; Dress Pattern Questionnaire (DPQ). Photographs and Physical Attractiveness Questionnaire (PAQ).

Dress Pattern Questionnaire (DPQ).

This instrument consist of 8 items and it is divided into 3 subscales, i.e. casual dressing (CD), indecent dressing (ID) and decent dressing (DD). The scale asses' participant's acceptance of a particular dress pattern. Bahamas, 
Foster and Fijiden (2002) reported an alpha reliability of 0.52-0.91. They also reported a test-retest reliability that range from 0.60-0.82 after a two-week interval.

Physical Attractiveness Questionnaire (PAI)

Colored Photographs of males and females Participants from the same study population to rate on a scale of 1 (most attractive) to 5 (most unattractive). The mean for the most attractive was 28.57 and the mean for the most unattractive was 28.38 .

\section{Sexual Harassment Questionnaire (SHQ)}

The instrument was developed by Levin (1999). It consists of 10 items. The items were scored on a $5-$ point Likert like scale, i.e., from 1 (strongly agree) to 5 (strongly disagree). It has an alpha reliability of 0.91 .

\section{Design}

The study made use of survey design. Three independent variables were manipulated. These were, Gender consisting of two levels i.e. (Males x Females), Physical Attractiveness (Attractive x Unattractive). The dependent variable was the level of sexual harassment. The design was therefore a 2 x 2 x 2 factotal design.

\section{Procedure}

Purposeful sampling procedure was used to enlist participants. They were contacted in the two hostels of the Yobe State University Damaturu. These were Hall A males hostel and the Hall B females hostel. They were told what they were required to do and their consent obtained.

20 volunteers made up of males and females first assessed the 100 participants into attractive and unattractive males and females. Thereafter, they were administered the dress pattern and sexual harassment questionnaires. Both the male and female participants were further categorized into decent dressers and indecent dressers. Of the 100 Participants, 53 were assessed as unattractive and 47 as attractive. 47 were categorized as decent dressers, while 53 as indecent dressers.

\section{Results}

The Tables below shows a statistical presentation of the results.

Table 1: Mean score on sexual harassment According to Gender

\begin{tabular}{|l|l|l|l|}
\hline Gender & Mean & Std Deviation & N \\
\hline Females & 29.26 & 3.932 & 50 \\
\hline Males & 27.68 & 3.836 & 50 \\
\hline Total & 28.47 & 28.47 & 100 \\
\hline
\end{tabular}

Table 1above indicates that, Females had a higher mean score (29.26) than their Male counterparts (27.68) on the sexual harassment scale.

Table 2: Mean score on sexual harassment According To Dress Pattern

\begin{tabular}{|l|l|l|l|l|}
\hline Dress Pattern & Mean & Std Deviation & N & Percentage \\
\hline Decent & 27.34 & 4.093 & 47 & 47 \\
\hline Indecent & 29.47 & 3.555 & 53 & 53 \\
\hline Total & 28.47 & 3.945 & 100 & 100 \\
\hline & & & & \\
\end{tabular}

Table 2:reviles that, the indecently dressed participants scored higher (29.47) on sexual harassment scale than the decently dressed participants (27.34).

Table 3: Mean score on sexual harassment According to Physical Attractiveness

\begin{tabular}{|l|l|l|l|}
\hline Physical Attractiveness & Mean & Std Deviation & $\mathrm{N}$ \\
\hline Unattractive & 28.38 & 4.020 & 53 \\
\hline Attractive & 28.57 & 3.900 & 47 \\
\hline Total & 28.47 & 3.945 & 100 \\
\hline
\end{tabular}

Table 3: shows that, the attractive participants scored slightly higher (28.57) than the unattractive participants (28.38) on sexual harassment scale. 
Table 4: ANOVA Summary Table of the Influence of Three Independent Variables

\begin{tabular}{|l|l|l|l|l|l|} 
Sources & $\begin{array}{l}\text { Type III Sum of } \\
\text { Square }\end{array}$ & DF & Mean Square & F & \\
Correlated Model & $252.212(\mathrm{a})$ & 7 & 36.030 & 2.572 & .018 \\
intercept & 77118.419 & 1 & 77118.419 & 5505.473 & .000 \\
\hline Gender & 82.437 & 1 & 82.437 & 5.885 & .017 \\
\hline DP & 132.851 & 1 & 132.851 & 9.484 & .003 \\
\hline PA & 10.066 & 1 & 10.066 & .719 & .399 \\
\hline Gender *DP & .015 & 1 & .15 & .001 & .974 \\
\hline Gender *PA & 16.216 & 1 & 16.216 & 1.158 & .285 \\
\hline DP PA & 4.248 & 1 & 4.248 & .303 & .583 \\
Gender*DP*PA & 47.979 & 1 & 47.979 & 3.425 & .067 \\
\hline Error & 1288.698 & 92 & 14.008 & & \\
\hline Total & 82595.000 & 100 & & & \\
\hline Corrected Total & 1540.910 & 99 & & & \\
\hline
\end{tabular}

$\mathbf{a}=\mathbf{R}$ squared $=.164($ Adjusted $\mathbf{R}$ squared $=\mathbf{1 0 0})$

Table 4: shows a statistically significant results for Gender $\mathrm{F}(1,100)=5.885, \mathrm{P}<0.05$. , and Dress Pattern F $(1,100)=9.484, \mathrm{P}<0.05$. The result was however not statistically significant for Physical Attractiveness $\mathrm{F}(1,100)=.719, \mathrm{P}<0.05$. There was slightly significant interaction effect of the three independent variables i.e., Gender *DP*PA, $\mathrm{F}(1,100)=3.425,<0.05$.

\section{Discussions}

The results above speak for themselves. They confirm the fears and concerns of the public on the potentially dangerous influence of indecent dressings. The higher scores of indecent dressed participants on sexual harassment scale is an indication that indecent dressing predisposes individuals to sexual harassment. The participants were drawn from the university, thus, bringing in mind the recent outcry in the Tertiary institutions about sexual harassment. The question often asked is who is harassing who? It is always assumed that Lecturers harass female students. The result of the study reveals that dress pattern is a major factor in sexual harassment. The implication of this finding is that if female students dress decently, they would have at least reduced the tally of sexual harassment.

Similarly results from literature provide explanations as to why indecently dressed individuals are higherly susceptible to sexual harassment. For example, Mashagoana (2002) found those who wear transparent and seductive cloths to have low self-concept thus, trading themselves as 'cheap whores', implying a lack of confidence in attracting a mate. This inferiority complex drives them into seductive dressing as a make-up to attract the potential mates. Gollub (2006) further explained that the crave for attention compel such individuals to wear 'funny' cloths that are seductive and revealing making them very prone to sexual harassment.

Significant result for gender is also a further confirmation that sexual harassment is masculine. For example, Buunk, et al (2006) found a high correlation between masculine ideology and sexual harassment. They found males to experience or report greater sex intention than females which they explained that it is responsible for males harassing females to satisfy such urges. In this particular study, the female score higher on sexual harassment scale than their male counterparts. Finding is also in line with Whatley and Wesieleski (2001) result for gender. In a society like ours, what is considered sexual harassment might be assumed to be normal masculine characteristics? This probably explains why the males score lower on sexual harassment scale.

Unexpectedly, the result did not support physical attractiveness as a factor in sexual harassment. One would expect that most attractive individuals would be highly susceptible to sexual harassment because they possess the potentials for attracting attention. Since it was not supported, it implies that physical attractiveness by itself is not an issue in sexual harassment as such, but more of the issue of decency or indecency in appearance. This finding is also informative in the sense that when we dress decently and we are physically attractive, we earn more respect rather than harassment.

From the result of the study and the interaction effect of the three variables of Gender, Dress Pattern and Physical Attractiveness, sexual harassment would be experienced depending on whether the individual is a female, is physically attractive and dresses indecently. The implication is that females should be mindful of the fact that whether they are physically attractive or not, if they dress indecently they would be exposing themselves to sexual harassment. 


\section{References}

[1] Adebayo, (2000). Dress pattern in Nigeria Universities, Family, Religion and School and Peer Influence. http//www.nigeriaEdu,htim

[2] Alper, J. (1993). The Pipe Line is Leaking Women all the way Long. Science,260, 409-411.

[3] Archer, J. (1996). Sex Differences in Social Behaviour. Are the social role and Evolutionary Explanations Compatible? American Psychologist, 51, 909-917.

[4] Aube, J, \& Koestner, R. (1992). Gender Characteristics and Adjustment: A Longitudinal Study. Journal of Personality and Social Psychology, 63, 485-493.

[5] Bachamas, Foster \& Eijnden. (2002). Dress Pattern in Caribbean University. Journal of Personality and Social Psychology, 641, 531-532.

[6] Bajos \& Marquet. (2000). Indecent Dressing on College Campuses. Environment and Behaviour, 9, 487-490.

[7] Bajos, Marquet \& Mcphail (2000). Social Class and Dress Oattern. Habitat Environment and Human Behaviour. New York: Housin Books. Pp 51-98.

[8] Bandura, A. (1997). Self-Efficacy of Control. New York: W. H. Freeman.

[9] Bandura, A. (1997). Theory of Self- Efficacy. Journal of Personality and Social Psychology, 51, 386-393.

[10] Barth, J. A, \& Raymond, P. (1995). No Conscious Sources of Sexual Harassment. Journal of Social Issues, 85-96.

[11] Bem, S. L. (1981). Gender Schema Theory: A Cognitive Account of Sex Typing. Psychological Review, 88, $354-364$.

[12] Berembaum, S. A. \& Hines, M. (1992). Early Androgen are Related to Childhood Sex-Typed of Preference. Psychological Sciences, 3, 203-206.

[13] Blakemore, J. E. O., Larue, A. A, \& Olejnike, A. B. (1979). Sex Appropriate to Preferences and the Ability to Conceptualize Toys as Sex-Role Related. Developmental Psychology, 15, 339- 340.

[14] Bogard, N. (1990). Why we need Gender to Understand Human Behaviour. Violence,5, 132-135.

[15] Brannon, L. (2002). Gender: Psychological Perspective. ( $3^{\text {rd }}$ Ed). Boston: A Pearson Education Company.

[16] Burris (2000). Biological Correlates in Understanding Indecent Exposure and Dress Behaviour. British Journal of Psychiatry, 186, 32-34.

[17] Buss, D. M. \& Schmitt, D. M. (1993). Sexual Strategies Theory: An Evolutionary Perspective of Human Mating. Psychological Review, 100, 204-232.

[18] Bussey, K. \& Bandura, A. (1984). Influence of Gender Constancy and Social Power on Sex-Linked Modeling. Journal of Personality and Social Psychology, 47, 1293-1302.

[19] Bussey, K. \& Bandura, A. (1992). Self-Regulating Mechanisms Governing Gender Development. Child Development, 63, 12361250.

[20] Buunk, S., \& Vanden E. (2000). Psychological Aspect of Indecent Dressing. American Psychologist, 53, $983-984$.

[21] Calaggie (2001). Nudists in Fashion. http//www.calaggie.com.htlm.

[22] Calaggie (2004). Borderline in Decency and Indecency in Sexuality and Compulsive Sexuality. Acta Psychiatrica Scandinaria, 72, 176-167.

[23] Carvajal, Garner \& Evans. (1998). System of Multicultural Integration. Journal of Abnormal Psychology. 100, $245-261$.

[24] Carvajal, Garner \& Evans. (2005). Personality of Indecent Dressers. Journal of Personality and Social Psychology, 73, 960-975.

[25] Castellow (1999). Sexual Harassment. http//.findarticles.com/p/articles.

[26] Catter, D. B. \& Lvey, G. D. (1988). Cognitive Aspect of Children's Early Sex-Role Development: The Influence of Gender Schemas in Preschool Memories and Preferences for Sex-typed Toys and Activities. Child Development, 59, $782-793$.

[27] Chodorow, N. (1979). The Reproduction of Mothering Psychoanalysis and the Society of Gender, Berkeley: University of California Press.

[28] Daily Newspaper (2008). Indecent Dressing Pattern and Sexual Harassment on Campuses in Nigerian Universities. Dress Pattern Review.

[29] Eagly, A. H. (1987). Sex Differences in Social Behaviour. A Social Role Interpretation. New Jersey: Eribaum.

[30] Eagly, A. H. (1987b). Reporting Sex Differences. American Psychologist, 42, 755-756.

[31] Eckes, C. (1994). Features of Men, Features of Women: Assessing Stereotypic Beliefs and Gender Stereotype. British Journal of Social Psychology, 33, 107-123.

[32] EEOC,(2002). Sexual Harassment: What it is and what you can do about it. Homepage:http//www.eeoc.gov. Retrieved 18/2/2010.

[33] Eijnden \& Yzer (2000). Pathological Aspect of Indecent Dress. American Sociological Review, 51, $347-363$.

[34] Emmerich, W \& Shepard, K. (1984). Cognitive Factors in the Development of Sex-Typed Preferences. Sex Role, 11 197-1007.

[35] Epstein, C. F. (1988). Descriptive Distinctions: Sex, Gender, and the Social Order. New Haven: Yale University Press.

[36] Euzobia, B. 2008) Indecent Dressing \& Sexual Harassment Review. University Press.

[37] Feingold, A. (1992b). Cognitive Gender Differences: A Developmental Perspective. Sex Role, $29,91-112$.

[38] Feldman, B. S. (1999). Understanding Psychology. Boston: McGraw-Hill Companies.

[39] Ferster, C. B. \& Skinner, B. F. (1957). Schedule of Reinforcement. New York: Appleton-Cenurycrofs.

[40] Fink, B \& Penton-Voak, I, (2002). Evolutional Psychology of Facial Attractiveness. Current Direction in Psychological Sciences, 11, 154-158.

[41] Foster (1996). Reward in Indecent Dresses. Journal of Personality and Social Psychology, 64, 224-226.

[42] Friedman, H. \& Zebrowitz, L. A. (1992). The Contribution of Typical Sex Differences in Facial Maturity to Sex Role Stereotype. Personality and Social Psychology Bulletin, 18, 430-438.

[43] Geis, F. I. (1993). Self-Fulfilling Prophesis: A Sociological Review of Gender. In Beall, A. E. And Stenber, R. J, (Ed.). The Psychology of Gender. New York: Guilford Press. Pp 9-54.

[44] Gerson, K. (1990). Continuing Controversies in the Sociology of Gender. Sociological Forum, 5, 301-310.

[45] Giddens, A. (1984). The Constitution of Society, Outline of the theory of Structuration. Berkley, C. A: University of California Press.

[46] Girija (2000). Dressing Versus Wearing Clothes: Dress Code for Women. http//www.hindu\%20/women.htm.

[47] Gollup (2000). Psychodynamic of Dress Pattern. Clinical Psychology Science and Practice, 9, 1-4.

[48] Harris, M. B. (1994). Gender of Subjects and Targets as Mediators. Journal of Applied Social Psychology, 24, 453-471.

[49] Hetherington, E. M. (1967). The Effect of Familial Variation on Sex-Typing, Parent-Child Similarity and Limitation in Children. In Hill, J. P. (Ed). Minnesota Symposia on Child Psychology Vol. 1. Mennesota University Press, Pp, 82-107.

[50] Hyde, J. S. (1984). How large are Gender Differences? A Developmental Meta-Analysis. Developmental Psychology, $20,722-786$.

[51] Jones, C. (1995). Sexual Harassment. New York: Facts on File. 


\section{The Psycho-Social Aspect of Indecent Dressing: Influence of Gender, Dress Pattern and Physical}

[52] Kohlberg, L. (1966). A Cognitive Development Analysis of Children's Sex Role Concept and Attitudes, In Maccoby, E. E. (Ed).The Development of Sex Differences. Stanford: Stanford University Press. Pp, 88-173.

[53] Lamb, M. E. \& Roopnarine, L. L. (1997). Peer Influences in Sex Role Development in Preschoolers. Child Development, 50, 1219 1222.

[54] Levy, G. D. \& Carter, D. B. (1989). Gender Schema, Gender Constancy and Gender Role Knowledge: The Role of Cognitive Factors in Preschooler's Gender Role Stereotypic Attitudes. Development Psychology, 25, 444-449.

[55] Levy, G. D. \& Fivush, R. (1993). Scripts and Gender: A new Approach for Explaining Gender Role Development. Developmental Review, 13, 126-146.

[56] Lobel, T. E. \& Menashri, J. (1993). Relationship of Conception of Gender Role Transgressions and Gender Constancy to GenderTyped Toy Preferences. Developmental psychology, 29, 150=155.

[57] Martin, C. L. \& Little J. K. (1990). The Role of Gender Understanding to Children's Sex-Typed Preferences and Gender Stereotypes. Child Development, 61, 1427-1439.

[58] Martin, C. L. (1987). A Ratio Measure of Sex Stereotyping. Journal of Personality and Social Psychology, 52, 489-499.

[59] Mashegoane, Solomon; Kyope, Ngoepe, Madakina \& Peltzer (2002). Dress Pattern and dress Behaviour. Journal of Nervous and Mental Disease, 173, 518-520.

[60] Neil (2006). Liberation and Feminist Expressions. American Journal of Psychiatry, 150, 1875-1877.

[61] Oliver, M. B. \& Hyde, J. S. (1993). Gender Differences in Sexuality: A Meta-Analysis. Psychological Bulletin, 11, 29-51.

[62] Perry, D. G; White, A. J.\& Perry, L. G. (1984) Does Early Sex-Typing Result from Children's Attitudes to Match their Behaviour to Sex Role Stereotypes? Child Development, 55, 2114-2121.

[63] Puhl, R. M. \& Boland, F. J. (2001). Predicating Female Attractiveness. Psychology Evolution and Gender, 27-46.

[64] Reis, H. T. \& Wright, S. (1982). Knowledge of Sex Roles Stereotypes in Children aged 3-5, Sex Role, 8, 1049-1056.

[65] Rhodes, G. \& Sumich, A. (1999). Are Average Facial Configurations Attractive only because of their Symmetry? Psychological Science, 10, 52-58.

[66] Samson, A. Prior, M, Smart, D. \& Oberklaid, F. (1993). Gender Differences in Childhood: Implication for a Peaceful World. Australian Psychologist, 28, 86-92.

[67] Sayers, J. (1986). Sexual Contradictions: Psychology Psychoanalysis and Feminism. London; Travis tock Publications.

[68] Serbin, L. A., Poolishta, K. K. \& Gulko, J. (1993). The Development of Sex Typing in Middle Childhood. Monographs of the society for Research in Child Development. 58, serial, No. 232.

[69] Signorella, M. L.(1987). Gender Schema, Individual Differences and Context Effect. In Liben, L. S. \& Signorella (Ed). Children's Gender Schemata. New Direction for Child Development, 38, 23-

[70] Slaby, R. G. \& Frey, K. S. (1975). Development of Gender Constancy and Selective Attention to Same Sex Models. Child Development, 46,849-856.

[71] Smuts, B. (1995). The Evolutionary Origins of Patriarchy. Human Nature. 6, 1-35.

[72] Szymansky, Sharon \& Cydney Puuman (1994). Sexual Harassment at Work: A Training Workbook for Working People. New York: The Institute.

[73] Taylor, J. K. (1999). What to do when you don’t want to call the Corps. New York: New York University Books. P, 8.

[74] Thompson, S. K. (1975). Gender Label and Early Sex Role Development, 46 339-347.

[75] Veraldi, Lorna, (1995). Academic Freedom and Sexual Harassment. Education Digest May $18^{\text {th }}, 61(1), 39$

[76] Weinraub, M. Clemens, L. P., Sockcloff, A., Ethridge, T., Gracely, E. \& Myers, B. (1984). The Development of Sex Role Stereotypes in the Third Year: Relationship to Gender Labelling, Gender Identity, Sex-Typed by Preferences and Family Characteristics. Child Development, 55, 1495-1503.

[77] West, C. \& Zimmerman, D. H. (1991). Doing Gender. In lorber and Farrel (Ed). The Social Construction of Gender. Newbury Park: C. A. Sage Publications.

[78] Whatley, M. A. \& Wasieleski, D. T. (2001). The Incidence of Sexual Harassment in Academia: A Pilot Study. Retrieved from http//www.radicalpedagogy.org/content/issue3-1/03whatley.html on $18^{\text {th }} / 2 / 2010$.

[79] White, A. J. (1987). Dress Pattern and Sexuality in Colleges. Journal of Psychotherapy, 29, 288-296. 